\title{
Application of Different Lime Rates and Phosphorus on Soil Physico-chemical Properties of Acid Soils in Western Ethiopia
}

\author{
Bodena Guddisa $^{1 *}$, Tamado Tana ${ }^{2}$ and Hirpa Legesse ${ }^{3}$ \\ ${ }^{1}$ Haro Sabu Research Center, Oromia Agriculture Research Institute, P.O. Box: 81265, \\ Addis Ababa, Ethiopia \\ ${ }^{2}$ Department of Plant Sciences, Haramaya University, P.O. Box: 138, Dire Dawa, Ethiopia
}

${ }^{3}$ Department of Plant Science, Faculty of Agriculture, Wollega University, P.O. Box: 395, Nekemte, Ethiopia

\begin{tabular}{|c|c|}
\hline Abstract & Article Information \\
\hline \multirow{3}{*}{$\begin{array}{l}\text { Soil acidity and phosphorus deficiency are the major yield limiting factors to crop production } \\
\text { in Haro Sabu area, western Ethiopia. Thus, a field experiment was carried out in } 2014 \text { main } \\
\text { cropping season from the end of June to the end of November at Haro Sabu to assess the } \\
\text { effect of lime and phosphorus rates on soil physico-chemical properties of the experimental } \\
\text { soil . The treatments were factorial combination of five rates of phosphorus }(0,11.5,23,46 \text {, } \\
\left.57.5 \mathrm{~kg} \mathrm{P}_{2} \mathrm{O}_{5}\right) \text { and four rates of lime }\left(\mathrm{CaCO}_{3}\right)\left(0,2.25,3 \text { and } 3.75 \text { tons ha }{ }^{-1}\right) \text { in randomized } \\
\text { complete block design and replicated three times. The pre soil analysis indicated that the soil } \\
\text { of experimental area was acidic }(\mathrm{pH}=5.31) \text { and low in available } \mathrm{P}\left(2.34 \mathrm{mg} \mathrm{kg}^{-1}\right) \text {. The soil } \\
\text { textural class was sandy clay loam with constituents of sand }(53 \%) \text {, clay }(19 \%) \text { and silt } \\
(28 \%) \text {. Application of both lime and phosphorus to the experimental plot increased } \\
\text { exchangeable Ca, available phosphorus and total nitrogen while decreased exchangeable } \\
\text { aluminum. Therefore, application of lime and phosphorous on acid soil improves the pH of } \\
\text { the soil, there by the availability of phosphorous and cations. } \\
\text { Copyright@2016 STAR Journal, Wollega University. All Rights Reserved. }\end{array}$} & $\begin{array}{l}\text { Article History: } \\
\text { Received : } 25-12-2015 \\
\text { Revised : 18-03-2016 } \\
\text { Accepted : } 23-03-2016\end{array}$ \\
\hline & \\
\hline & $\begin{array}{l}\text { *Corresponding Author: } \\
\text { Bodena Guddisa }\end{array}$ \\
\hline
\end{tabular}

\section{INTRODUCTION}

Soil acidity has become a serious threat to crop production in most highlands of Ethiopia in general and in the South, South Western and Western part of the country in particular. About $41 \%$ of potential arable land of Ethiopia is acidic (Workneh, 2013). Currently, it is estimated that about $67 \%$ of the total arable land of Wollega is affected by soil acidity (Abdenna et al., 2007). The production of groundnut under acidic conditions is low due to calcium and magnesium supply is reduced and plant growth suffers. Moreover, other beneficial nutrients are in deficient concentration in soil solution (Ranjit, 2005). Groundnut commonly responds to $\mathrm{Ca}$ additions under acid soil conditions, due to the fact that $\mathrm{Ca}$ is required for adequate pod filling. In acid soils, availability of certain nutrients like aluminum, iron and manganese increases due to higher dissolution and at times becomes toxic. In strongly acidic conditions, phosphorus reacts with active iron and aluminum (AI) forming insoluble phosphates. When the $\mathrm{pH}$ falls below 6.0 , the availability of nutrients such as phosphorus, potassium, calcium, and magnesium decreases. The main purpose of lime in dealing with soil acidity particularly on legume is due to its effect on improving crop responses to fertilizers by improving nutrient availability and uptake especially phosphorus, reducing aluminum(Al) toxicity and promoting the activities of such desirable organisms as rhizobia bacteria which fix nitrogen for legumes (Nekesa, 2007). In western parts of the country, the farmers shifted their land to produce relatively acid tolerant crops such as maize, and in some parts they left their land as a fallow for two to four years without any cultivation hence even in some parts the land left only for grazing (Abdenna et al., 2007). In addition, no work has been done especially in the western part of the country to evaluate the effect of phosphorus and lime application on groundnut. Therefore, the objective of this study is to determine the effect of Lime and Phosphors rates on soil physic-chemical properties of the experimental soil of Haro sabu, in western Ethiopia.

\section{MATERIALS AND METHODS}

\section{Description of the Study Area}

The study was conducted at Haro Sabu Agricultural Research Center (HSARC) during the main cropping season of 2014 from June to November. The center is located in western Ethiopia, Oromiya Regional state at $550 \mathrm{~km}$ away to the west from Addis Ababa. It lies at latitude of $8^{\circ} 52$ '51" $N$ and longitude of $35^{\circ} 13$ '18" $E$ and altitude of 1515 meters above sea level. According to the weather data recorded by the Asosa meteorological substation at Haro Sabu, the average annual rainfall of the study site is $1100 \mathrm{~mm}$ with uni-modal distribution pattern and the monthly mean minimum and maximum temperatures are between $11-15.7^{\circ} \mathrm{C}$ and 23.8 to $33.4^{\circ} \mathrm{C}$ 


\section{Bodena Guddisa et al.,}

with warm humid climate conditions. The rainy season ranges from April to October.

The composite soil analysis done before planting at Nekemte soil libratory indicated that the soil type of the experimental site is reddish brown in color with soil textural class of sandy loam. The soil has a pH of 5.31 which is acidic, available phosphorus $2.34 \mathrm{mg} \mathrm{kg}^{-1}$ rated as low, total nitrogen of $0.275 \%$ rated as medium, Exchangeable $\mathrm{Ca}^{2+}\left(5.379 \mathrm{cmol}_{\mathrm{c}} \mathrm{kg}^{-1}\right)$ rated as medium according to the rating of Landon (1991) and Exchangeable acidity $\left(\mathrm{Al}^{3+}\right)$ of $1.4 \mathrm{cmol}_{\mathrm{c}} \mathrm{kg}^{-1}$ rated as very high according to Moore (2001) (Table 1).

\section{Treatments and Experimental Design}

The treatments consisted of five rates of phosphorus $\left(0,11.5,23,46,57.5 \mathrm{~kg} \mathrm{P}_{2} \mathrm{O}_{5}\right)$ and four rates of lime $(0$, $2.25,3$ and 3.75 tons $\mathrm{ha}^{-1}$ ) in a factorial combination in randomized complete block design and replicated three times. Thus, there were twenty (20) treatment combinations. Treatments were assigned to each plot randomly. The gross plot size of each experimental plot was $10.08 \mathrm{~m}^{2}(3.6 \mathrm{~m} \times 2.8 \mathrm{~m})$.

\section{Soil Sampling and Analysis}

Soil sample was taken at a depth of $0-30 \mathrm{~cm}$ from randomly selected spots in $Z$ pattern across the experimental field with five spots collected per plot before planting and after harvest from each plot by using auger. From the collected soil samples one composite sample before planting and twenty composite samples after harvest were prepared by bulking of the soils collected from similar treatments of different block and minimized to the number of treatments per block for analysis to determine the physico-chemical properties of the soil of the experimental site. The samples were air-dried, thoroughly mixed and ground and sieved to pass through a $2 \mathrm{~mm}$ sieve for analysis of soil nutrients and finely pounded to pass $0.2 \mathrm{~mm}$ for organic matter analysis. From this mixture, a sample weighing $1 \mathrm{~kg}$ was filled into plastic bag and taken to Nekemte soil laboratory for the analysis. The soil samples were analyzed for soil texture, total nitrogen, $\mathrm{pH}$, organic matter, available phosphorus, exchangeable Al and cation exchange capacity (CEC).

Soil particle size distribution (soil texture) was determined in the laboratory by using Bouyoucos
Sci. Technol. Arts Res. J., Jan-March 2016, 5(1): 84-87

hydrometer method as described by Day (1965). Total nitrogen was determined following kjeldahl procedure as described by Cotteinie (1980); the soil pH was measured with digital $\mathrm{pH}$ meter on a 1:2.5 soil: water suspension after the suspension was stirred using an automatic stirrer for 30 minute (Page, 1982); organic carbon was determined by the oxidation of organic carbon with potassium dichromate $\left(\mathrm{K}_{2} \mathrm{Cr}_{2} \mathrm{O}_{7}\right)$ in which the reactions were facilitated by the heat generated two volume of concentrated $\mathrm{H}_{2} \mathrm{SO}_{4}$ and one volume of $1 \mathrm{~N} \mathrm{~K}_{2} \mathrm{Cr}_{2} \mathrm{O}_{7}$ solution according to Walkley and Black method as described by Allison (1965).

The available phosphorus was measured using Bray II method by shaking the soil samples with extracting solutions of $0.03 \mathrm{M}$ ammonium fluoride in $0.1 \mathrm{M}$ hydrochloric acid as described by Bray and Kurt (1945); Exchangeable $\mathrm{Ca}$ was measured from the extract with atomic absorption spectrophotometer. Exchangeable acidity ( $\mathrm{Al}$ and $\mathrm{H}$ ) was determined from a neutral $1 \mathrm{~N} \mathrm{KCl}$ extracted solution through titration with standard $\mathrm{NaOH}$ solution based on the procedure described by McLean (1965). The parameters analyzed after harvesting the treatments were available phosphorus, $\mathrm{pH}$, calcium and exchangeable Al.

\section{RESULTS AND DISCUSSION}

\section{Soil Physico-Chemical Properties of Experimental Site}

From the soil analysis result before sowing it was apparent that the soil textural class was sandy clay loam with constituents of sand (53\%), clay (19\%) and silt (28\%) which is ideal for groundnut as the crop is grown mostly on light-textured soils ranging from coarse and fine sands to sandy clay loams (Onwueme and Sinha, 1991). The soil $\mathrm{pH}\left(\mathrm{H}_{2} \mathrm{O}\right)$ of 5.31 rated as acidic, total nitrogen $(0.275 \%)$ is as medium, available phosphorus $(2.34 \mathrm{mg}$ $\mathrm{kg}^{-1}$ ) as low, exchangeable calcium $\left(5.379 \mathrm{cmol}_{\mathrm{c}} \mathrm{kg}^{-1}\right.$ ) as moderate according to the classification by Landon (1991) and Aluminium concentration of $1.4 \mathrm{cmol}_{\mathrm{c}} \mathrm{kg}^{-1}$ as very high according to the rating of Moore (2001) (Table 1). Thus, moderate to low mineral content of the soil implied that there was necessity of applying nitrogen, phosphorus and calcium to the experimental plot of the study area.

Table 1: Major soil physico-chemical properties of the experimental site before planting

\begin{tabular}{lccc}
\hline \multicolumn{1}{c}{ Soil Characters } & Value & Rating & Reference \\
\hline A. Particle size distribution & & & \\
Sand (\%) & 53 & & \\
Silt (\%) & 28 & & \\
Clay (\%) & 19 & & Sandy Clay Loam $(1991)$ \\
\hline \multicolumn{1}{c}{ Textural Class } & & & Landon (1991) \\
\hline B. Chemical analysis & 5.31 & High & Landon (1991) \\
Soil pH & 6.3 & Medium & Landon (1991) \\
Organic matter (\%) & 0.275 & Low & Landon (1991) \\
Total N (\%) & 2.34 & Moderate & Moore (2001) \\
Available P (mg kg $\left.{ }^{-1}\right)$ & 5.379 & Very high &
\end{tabular}




\section{Bodena Guddisa et al.,}

The analysis of the experimental soil after harvest for $\mathrm{pH}$, exchangeable Aluminum, exchangeable $\mathrm{Ca}$, available phosphorus and total nitrogen is indicated in Table 3 . The result revealed that exchangeable $\mathrm{Ca}$, available phosphorus and total nitrogen were increased while exchangeable aluminum decreased after the application of lime and phosphorus to the experimental plot. However, the range of $\mathrm{pH}$ change was only from 5.31 to 5.66 with treatment of the highest rate of 3.75 ton lime ha 1 (Table 2) which could be due to the inactivation of aluminum and iron which correspondingly increased the level of soil pH (Mesfin, 2007).

This small change might be due to high organic matter content of the soil that influences the change in $\mathrm{pH}$ which is attributed by its high buffering property. During this situation the soil could resist sharp change in $\mathrm{pH}$ with the addition of bases. The other reason might be when the exchangeable site was saturated with basic cations further addition of the basis might less increase the cation fixed to the sites. In this regards, Mesfin (2007) reported the larger the clay and organic matter content, the higher the cation exchange capacity and the greater the buffer capacity.

The result obtained from composited soil analysis showed that the treatments with $23 \mathrm{~kg} \mathrm{P}_{2} \mathrm{O}_{5}$ and lime rate of 3 ton ha ${ }^{-1}$ gave an increase of $0.56 \% \mathrm{pH}, 82.62 \% \mathrm{Ca}$ and $94.66 \%$ available phosphorus over the control (Table 2). This implies that lime application possibly increased the $\mathrm{pH}$, calcium content of the soil and available phosphorus so that groundnut utilized the nutrients for proper growth and development that lead to higher yield. In agreement with this result, Nekesa (2007) described that lime improves the crop responses to fertilizers by improving nutrient availability and uptake especially phosphorus, reducing aluminum (Al) toxicity and promoting the activities of such desirable organisms as rhizobia bacteria that fix nitrogen for legumes.

On the other hand, the application of 3 ton lime ha ${ }^{-1}$ to the soil reduced $\mathrm{Al}^{3+}$ level by $92.65 \%$ relatively from 1.4
Sci. Technol. Arts Res. J., Jan-March 2016, 5(1): 84-87

$\mathrm{cmol}_{\mathrm{c}} \mathrm{kg}^{-1}$ before planting to $0.103 \mathrm{cmol}_{\mathrm{c}} \mathrm{kg}^{-1} \mathrm{Al}^{3+}$ after harvest of the crop. Moreover, the addition of 3 tons lime and phosphorus rate of $23 \mathrm{~kg} \mathrm{P}_{2} \mathrm{O}_{5} \mathrm{ha}^{-1}$ increased the level of $\mathrm{Ca}$ in the soil by $50.20 \%$ from 5.379 to 8.079 $\mathrm{cmol}_{\mathrm{c}} \mathrm{kg}^{-1}$ and phosphorus by $83.79 \%$ from 2.24 to 4.117 $\mathrm{mg} \mathrm{kg}^{-1}$ after harvest of the crop (Table 2). This was probably correlated with yield increase over the control treatment because of $\mathrm{Ca}$ supply and thereby enhancing the availability of phosphorus of the plot where lime was added. In agreement with this result, Barasa et al. (2013) stated that use of lime alone or triple super phosphate in combination with lime increased soil nutrients $\mathrm{P}$ and $\mathrm{Ca}$ required for plant growth either from direct release from the inputs or improving the solubility of phosphorus from insoluble $\mathrm{Al}$ and $\mathrm{Fe}$ compounds which are commonly associated with acid soils. Similarly, Mesfin (2007) described liming inactivated aluminum and iron in acidic soil which resulted in increased phosphate availability to plants.

Similarly, the application of the highest rate of 3.75 ton ha $^{-1}$ lime lowered the $\mathrm{Al}^{3+}$ level by $94.07 \%$ from 1.4 to $0.083 \mathrm{cmol}_{\mathrm{c}} \mathrm{kg}^{-1}$, whereas increased $\mathrm{Ca}$ content of the soil by $60.23 \%$ from 5.379 to $8.619 \mathrm{cmol}_{\mathrm{c}} \mathrm{kg}^{-1}$ and addition of highest rate of $57.5 \mathrm{P}_{2} \mathrm{O}_{5} \mathrm{~kg} \mathrm{ha}^{-1}$ at this lime rate increased the phosphorus in the soil by $36.79 \%$ from 2.24 to $3.064 \mathrm{mg} \mathrm{kg}^{-1}$ after harvest, respectively (Table 2). The reduction of $\mathrm{Al}$ after the application of lime probably associated with inactivation of $\mathrm{Al}$ and Iron from the soil exchangeable sites due to the saturation of sites with bases and decreasing solubility potential of Al when $\mathrm{pH}$ of the soil raise.

As the rate of lime and phosphorus application increases, the soil characteristic parameters were increased with increase in lime and phosphorus concentration (Table 3). Maximum pH (5.53) was recovered, when 3.75 ton/ha ${ }^{-1}$ lime applied with relatively higher rate of phosphorous (Table 3). This increase in $\mathrm{pH}$ of the soil increased the availability of cations under acid soils in the study area.

Table 2: Percent change of soil $\mathrm{pH}$, exchangeable calcium $(\mathrm{Ca})$ and Aluminum $(\mathrm{Al})$ and available phosphorus $(\mathrm{P})$ after harvest of the crop in response to liming and phosphorus application

\begin{tabular}{|c|c|c|c|}
\hline \multicolumn{4}{|c|}{ When 3 Ton Lime and $23 \mathrm{~kg} \mathrm{P}_{2} \mathrm{O}_{5} \mathrm{ha}^{-1}$ Applied } \\
\hline Soil Chemical Analysis & Before Planting & After Harvest & $\%$ Change \\
\hline $\mathrm{pH}$ & 5.31 & 5.34 & 0.56 \\
\hline Exch. $\mathrm{Ca}\left(\mathrm{cmol}_{\mathrm{c}} \mathrm{kg}^{-1}\right)$ & 5.379 & 8.079 & 50.20 \\
\hline Exch. Al $\left(\mathrm{cmol}_{\mathrm{c}} \mathrm{kg}^{-1}\right)$ & 1.4 & 0.103 & 92.65 \\
\hline Avail. $\mathrm{P}\left(\mathrm{mg} \mathrm{kg}^{-1}\right)$ & 2.24 & 4.117 & 83.79 \\
\hline \multicolumn{4}{|c|}{ When 3.75 Ton Lime and $57.5 \mathrm{~kg} \mathrm{P}_{2} \mathrm{O}_{5}$ ha $^{-1}$ Applied } \\
\hline $\mathrm{pH}$ & 5.31 & 5.66 & 6.60 \\
\hline Exch. $\mathrm{Ca}\left(\mathrm{cmol}_{\mathrm{c}} \mathrm{kg}^{-1}\right)$ & 5.379 & 8.619 & 60.23 \\
\hline Exch. Al $\left(\mathrm{cmol}_{\mathrm{c}} \mathrm{kg}^{-1}\right)$ & 1.4 & 0.083 & 94.07 \\
\hline Avail. $\mathrm{P}\left(\mathrm{mg} \mathrm{kg}^{-1}\right)$ & 2.24 & 3.064 & 36.79 \\
\hline
\end{tabular}


Table 3: Soil chemical property of experimental field at Haro Sabu after harvest

\begin{tabular}{|c|c|c|c|c|c|c|c|c|}
\hline \multicolumn{2}{|c|}{ Treatments } & \multirow[b]{2}{*}{$\begin{array}{c}\mathrm{pH} \\
\left(\mathrm{H}_{2} \mathrm{O}\right)\end{array}$} & \multicolumn{4}{|c|}{ Exch. acidity cmolc kg-1 and exch. Cations } & \multirow[b]{2}{*}{$\begin{array}{c}\text { Total N } \\
(\%)\end{array}$} & \multirow[b]{2}{*}{$\begin{array}{c}\text { Organic } \\
\text { matter (\%) }\end{array}$} \\
\hline $\begin{array}{c}\text { Lime } \\
\text { rate (t/ha) }\end{array}$ & $\begin{array}{c}P \\
\text { (kg ha-1) }\end{array}$ & & $\begin{array}{l}\text { Acidity } \\
\left(\mathrm{Al}_{3}+\right)\end{array}$ & $\mathbf{C a}$ & Mg & $\begin{array}{c}\text { Av. P } \\
(\mathrm{mg} \mathrm{kg}-1)\end{array}$ & & \\
\hline 0.0 & 0.0 & 5.31 & 1.40 & 4.42 & 2.22 & 2.12 & 0.39 & 7.80 \\
\hline 2.25 & 0.0 & 5.33 & 0.08 & 8.64 & 2.51 & 2.01 & 0.39 & 7.81 \\
\hline 3.00 & 0.0 & 5.35 & 0.16 & 7.50 & 2.77 & 4.11 & 0.42 & 8.33 \\
\hline 3.75 & 0.0 & 5.47 & 0.21 & 8.02 & 1.13 & 2.06 & 0.40 & 8.06 \\
\hline 0.0 & 11.5 & 5.31 & 0.10 & 8.22 & 2.51 & 4.10 & 0.42 & 8.47 \\
\hline 2.25 & 11.5 & 5.32 & 0.25 & 7.69 & 1.85 & 2.05 & 0.39 & 7.83 \\
\hline 3.0 & 11.5 & 5.36 & 0.12 & 7.62 & 2.63 & 2.06 & 0.41 & 8.22 \\
\hline 3.75 & 11.5 & 5.51 & 0.20 & 9.72 & 3.43 & 4.98 & 0.47 & 9.43 \\
\hline 0.0 & 23 & 5.28 & 0.02 & 8.70 & 2.37 & 2.06 & 0.39 & 7.79 \\
\hline 2.25 & 23 & 5.32 & 0.06 & 8.41 & 2.36 & 4.10 & 0.39 & 7.83 \\
\hline 3.00 & 23 & 5.34 & 0.10 & 8.08 & 2.06 & 4.12 & 0.39 & 7.79 \\
\hline 3.75 & 23 & 5.49 & 0.23 & 7.18 & 2.52 & 4.11 & 0.39 & 7.76 \\
\hline 0.0 & 46 & 5.31 & 0.06 & 8.93 & 3.08 & 4.11 & 0.41 & 8.12 \\
\hline 2.25 & 46 & 5.34 & 0.17 & 9.31 & 1.65 & 2.07 & 0.43 & 8.53 \\
\hline 3.00 & 46 & 5.45 & 0.12 & 8.91 & 2.48 & 2.03 & 0.42 & 8.36 \\
\hline 3.75 & 46 & 5.53 & 0.04 & 9.31 & 0.62 & 2.06 & 0.40 & 7.99 \\
\hline 0.0 & 57.5 & 5.29 & 0.16 & 8.36 & 1.70 & 2.00 & 0.38 & 7.65 \\
\hline 2.25 & 57.5 & 5.33 & 0.02 & 9.17 & 1.67 & 4.17 & 0.39 & 7.89 \\
\hline 3.00 & 57.5 & 5.48 & 0.00 & 9.63 & 0.15 & 6.15 & 0.36 & 7.19 \\
\hline 3.75 & 57.5 & 5.66 & 0.08 & 8.62 & 3.15 & 3.07 & 0.41 & 8.09 \\
\hline
\end{tabular}

\section{CONCLUSIONS}

Soil acidity affects plant growth by reducing nutrient availability such as calcium and magnesium supply and uptake of phosphorus as well due to its fixation. Liming soil acidity particularly on legume has the principal contribution of improving crop responses to fertilizers by improving nutrient availability and uptake especially phosphorus, reducing aluminum(Al) toxicity and promoting the activities of such desirable organisms as rhizobia bacteria which fix nitrogen for legumes. Liming increase the calcium content of the soil which is important for groundnut pod filling by creating proper $\mathrm{pH}$ for the crop to take the nutrients around root zone.

\section{Conflict of Interest}

None declared.

\section{REFERENCES}

Abdenna Deressa., Negassa Chewaka and Tilahun Geleto (2007). Inventory of Soil Acidity Status in Crop Lands of Central and Western Ethiopia. "Utilisation of diversity in land use systems: Sustainable and organic approaches to meet human needs". Tropentag, October 9-11, 2007, Witzenhausen.

Allison, L.E. (1965). Organic carbon pp. 1367-1378. In: Black, D.D. Evans, J.L. White, L.E. and Ensiminger, F.E. Clark, (eds.). Methods of soil analysis. Am. Soc. Agron. Monograph No. 9, Madison, Wisconsin, USA.

Barasa, J.N., Omami, E.N., Okalebo, J.R. and Othieno C.O. (2013). Effect of Lime and Phosphorus Fertilizer applications on performance of French Beans in Uasin Gishu District, Kenya. Global Journal of Biology, Agriculture and Health Science 2(3): 35-41.

Bray, R.H., and Kurtz, L.T. (1945). Determination of total, organic and available forms of phosphorus in soils. Soil Science 59: 39-45.

Cotteinie, A. (1980). Soil and Plant Testing as a Base of fertilizer Recommendations. Soils Bulletins, No. 38, FAO, Rome.

Day, P.R. (1965). Hydrometer method of particle size analysis In: C.A. Black (ed.). Methods of soil analysis. Am. Soc.agron. No.27. Madison. Wisconsin. pp. 562-563.
Landon, J.R. (1991). Tropical soil manual: a handbook for soil survey and agricultural land evaluation in the tropics and sub tropics. Longman Scientific and Technical, Longman Group, UK Ltd.

McLean, K.O. (1965). Aluminum. pp. 978-998. In: C.A. BLACK (Ed.) Methods of soil analysis: Agro No. 9. Part 2. Am soc. Agron, Madison, Wisconsin, USA.

Mesfin Abebe. (2007). Nature and management of acid soils in Ethiopia. www.eiar.gov.et/Soil/soils_acid.pdfon grain legumes Addis Ababa Ethiopia. Accessed on March 24, 2014.

Moore, Geoff. (2001). Soil Guide: A Hand Book For Understanding and Managing Agricultural Soils. Compiled and Edited By Geoff Moore, Bulletin 4343.

Nekesa, A.O. (2007). Liming Effects of Minjingu Phosphate Rock and Agricultural Lime on Maize, Groundnut and Soybean yields on acid soils of Western Kenya. .M.Sc. Thesis, Moi University .Eldoret Kenya.

Onwueme, I.C. and Sinha, T.D. (1991). Field crop production in Tropical Africa, Principles and practice, CTA (Technical Center for Agriculture and Rural Cooperation). The Netherlands.

Page, A.L. (1982). Methods of soil analysis. Part II. Chemical and microbiological properties. American Society of Agronomy, Mandison. USA. pp 62-67.

Ranjit, R. (2005). Response of Groundnut genotypes to lime and Phosphorus levels in Coastal Alluvial Soil of North Karnataka. Published M.Sc Thesis submitted to the Department of Soil Science and Agricultural Chemistry College of Agriculture, University of Agricultural Sciences, Dharwad acid soil in Congo.

Workneh Bekere (2013). Liming Effects on Yield and Yield Attributes of Nitrogen Fertilizer and Bradyrhizobia Inoculated Soybean (Glycine max L.) Grown in Acidic soil at Jimma, South estern Ethiopia. Journal of Biology, Agriculture and Healthcare 3(14): 44-46. 